\title{
A PROMISE WITH "OPTION TO CANCEL" AS VALUABLE CONSIDERATION
}

A promise creates no legally enforceable duty unless some consideration is given for it; but generally the law does not investigate as to its value or amount. This led Mr. Justice Holmes to say: "This being so, consideration is as much a form as a seal." " The reaction against - mere "formality" has led others to suggest that the time has come for the abolition of the requirement of consideration as well as for the abolition of the common-law operation of a seal. It is believed that the abolition of the second would be undesirable ${ }^{2}$ and that an attempt to abolish the first would fail. As Dean Pound, speaking of nudum pactum, says: "there is something more than the fetish of a traditional Latin phrase with the hallmark of Roman legal science behind our reluctance to enforce all deliberate promises simply as such."

In Gurfein u. Werbelovsky (I922) 97 Conn. 703, I18, Atl. 32, speaking of a bilateral contract, the court said: "Of course, the right to enforce the buyer's promise to buy is such a consideration, and if that right existed, even for the shortest space of time, it is enough to bring the contract into existence." Here the terms of the agreement were as follows: "We have this day accepted your order for 5 cases of plate glass. ... The above cases are to be shipped within 3 months from date. You to have the option to cancel the above order before shipment." The buyer insistently demanded the goods and finally sued for damages for refusal to ship. The court held that the "option to cancel" did not render the agreement unenforceable.

The contract was bilateral, creating a duty to pay as well as a duty to ship, each promise being the consideration for the other. The "option to cancel" possessed by the buyer meant that he had the legal power of extinguishing the mutual duties. This power would die instantly upon shipment by the defendant. The possession of such a power does not in itself nullify the duty of the buyer who possesses such power. It does not give him the privilege of not paying. It merely gives him the power to create such a privilege. The exercise of the power requires a notice sent by the buyer and received by the

${ }^{1}$ Krell v. Codinan (I89I) I54 Mass. 454,28 N. E. 578.

${ }^{2}$ See the doubtful case of Fountain $v$. Stein (1922) 97 Conn. 6r9, II8 Atl. 47; (I923) 32 YaLE LAW JourNaI, 409. There ought to be available one method of making an enforceable promise without invoking the doctrine of consideration.

${ }^{3}$ Introduction to the Philosophy of Laze (I922) 280.

Anson, Contract (Corbin's ed. I9I9) II9, note 2 : "The requirement of consideration is not merely to test the promisor's intention to assume a legal duty. It seems more accurate to say that consideration is the criterion to determine whether the customary notions of justice prevailing in the community require the legal enforcement of a promise. In this aspect the idea of consideration assimilates itself to the idea of canusa in the Roman and Continental law, and the two ideas differ only where the mores of the two communities differ." 
seller before shipment of the goods. ${ }^{4}$ It could not be exercised merely by refusing to receive the goods or by refusing to pay.

The decision is correct in analysis and sound in policy. The consideration given by the plaintiff was of substantial value and did not approach a mere "form."

A. L. C.

It is universally acknowledged that a thief acquires no title to a thing stolen and can pass no better title to a purchaser, even though the purchaser buys in good faith. So generally accepted is this rule that a citation of authorities is unnecessary. Its logic, however, is questionable. A thief does not get a complete title, but analysis shows that he does acquire an interest which is of some value. He has possessionthat is, physical custody plus an intention to exclude all others-and although wrongful, yet if left undisturbed for the statutory limitation period, will ripen into a perfect legal title. Furthermore, it seems that if he is disturbed by anyone except the true owner or one claiming through or on behalf of the latter, his possession will be protected. It is true that diligent search has failed to disclose a reported case in which the precise point has arisen, ${ }^{1}$ but no good reason appears why the well settled rule that possession, even though wrongfully acquired, will be protected against trespassers, ${ }^{2}$ should not apply. "The law .protects possession to preserve the peace. Why then should not the same protection be afforded the possession of a thief that is given to the possession acquired by trespass or conversion, which does not amount to a crime. $^{3}$ The application of the rule that a thief acquires no title may

The court said: ". ... the contract is framed on the theory that it remains enforceable by either party unless and until the plaintiff brings home notice of cancellation before shipment."

"It may be observed that the plaintiff, so far as his detrimental jural relations are concerned, is in the same legal position that he would be in if he made an ordinary offer to buy glass to be accepted only by actual shipment of the glass ordered. In such case his duty to pay would be enforceable only after shipment. So is it in the instant case. In each case he is under liability to the creation of an enforceable duty to pay by the defendant's exercise of his power by shipment of the glass; and in each case he has power to revoke by a notice delivered. But this does not prove that Werbelovsky was not bound to ship, even though in the case of an unaccepted offer the offeree is not bound to ship. In each case the jural position of the plaintiff is detrimental. In the instant case he offered to put himself in that position in return for the defendant's promise to ship and the defendant accepted by promising. In the supposed case the plaintiff put himself in the detrimental jural position for nothing, and the offeree was not bound to ship because he had promised nothing.

${ }^{1}$ See Bordwell, Property In Chattels (IgI6) 29 HARv. L. Rev. 374; see (I92I) 34 HARv. L. REv. 681 (transfer of stolen automobile purchased by bankrupt in good faith held a transfer of property within meaning of Bankruptcy Act).

'Darlington, Personal Property (I89r) 37, note I.

'See Anderson v. Gouldberg (1892) 5I Minn. 294, 53 N. W. 636. 